\title{
Allicin-rich garlic extract alleviates high-fat diet-induced complications in rats: A nutrigenomic study
}

\author{
1,2Neha Mahajan, 1,3Vijay Kumar, 1,2Ruchika Maurya, \\ ${ }^{4}$ Pragyanshu Khare, ${ }^{6}$ Priyanka Mangal, ${ }^{7}$ Rohini Verma, \\ 1,5Vibhu Kumar, ${ }^{1,5}$ Jasleen Kaur, ${ }^{7}$ Sanjay Madhukar \\ Jachak, ${ }^{1}$ Kanthi Kiran Kondepudi, ${ }^{1 *}$ Mahendra Bishnoi \\ ${ }^{1} T R(i) P$ for Health Laboratory, Centre of Excellence in Functional \\ Foods, Department of Food and Nutritional Biotechnology, \\ National Agri-food Biotechnology Institute (NABI), \\ Knowledge City-Sector-81, SAS Nagar, Punjab 140306, India; \\ ${ }^{2}$ Regional Centre for Biotechnology, Faridabad-Gurgaon \\ expressway, Faridabad, Haryana 121001, India; \\ ${ }^{3}$ Department of Biotechnology, Panjab University, Sector-25, \\ Chandigarh 160014, India; \\ ${ }^{4}$ Department of Anesthesiology, UniClinic, Erlangen, Friedrich- \\ Alexander-Universität, Erlangen-Nürnberg, Germany; \\ ${ }^{5}$ Pharmacology Division, University Institute of Pharmaceutical \\ Sciences (UIPS), Panjab University, Chandigarh 160014, India; \\ ${ }^{6}$ Department of Pharmacology and Toxicology, National Institute \\ of Pharmaceutical Education and Research (NIPER), SAS Nagar \\ 160062, Punjab, India; \\ ${ }^{7}$ Department of Natural Products, National Institute of \\ Pharmaceutical Education and Research (NIPER), SAS Nagar \\ 160062, Punjab, India.
}

Corresponding author: Mahendra Bishnoi, PhD

Scientist E, TR(i)P for Health Laboratory Centre of Excellence in Functional Foods, Department of Food and Nutritional Biotechnology, National Agri-food Biotechnology Institute (NABI), Knowledge City-Sector-81, SAS Nagar, Punjab 140306, India.

Phone: +91- 172-5220261, +91-9914469090

E-mail address: mbishnoi@nabi.res.in, mbishnoi@gmail.com

\begin{abstract}
The remedial effects of garlic in various metabolic complications have been attributed to a variety of organosulfur compounds such as allicin, diallyl sulfides, alliin and allyl trisulfides. The present study was designed to prepare an aqueous extract of garlic with stable allicin and its biological evaluation on tissue-specific nutrigenomic effects in the prevention of High-fat diet (HFD)-induced weight gain and related complications in Sprague-Dawley (SD) rats. Aqueous Allicin-rich garlic extract (ARGE) was prepared and characterized for stability of allicin using HPLC. For biological evaluation, animals were fed with either normal pellet diet (NPD), HFD, HFD along with ARGE $(1 \mathrm{ml} / \mathrm{kg}$ p.o.) and ARGE per se $(1 \mathrm{ml} / \mathrm{kg}$ p.o.) for 16 weeks. Chronic administration of ARGE prevented HFD-induced weight gain, adipose tissue hypertrophy, insulin resistance and improved overall glucose homeostasis. Transcriptional analysis of different tissues highlighted that ARGE promoted browning, improved glucose metabolism and appetite regulation. Overall, this study presents ARGE as a potential nutraceutical for the prevention of obesity and related comorbidities.
\end{abstract}

Key words: ARGE, allicin-rich garlic extract; TRPA1; obesity; BAT, brown adipose tissue; WAT, white adipose tissue; DADS, diallyl disulfides; DATS, diallyl trisulfides; insulin resistance; WAT browning; gut hormones.

\section{INTRODUCTION}

Global obesity is increasing tremendously in recent years [1]. Obesity and overweight are major risk factors for the development of many non-communicable diseases, including - type 2 diabetes, cardiovascular diseases, hypertension and cancers [2,3]. Effective and safe treatments for the suppression of obesity and related disorders are limited. Although, there are many FDA-approved drugs in the market but due to their limited safety profile, use of dietary food constituents with potential to prevent the development of obesity has emerged as a novel strategy to tackle the disease $[4,5]$.

Garlic (Allium sativum), belongs to a group of herbaceous and ornamental plants (subfamily Alloideae) with nutritional, medicinal and pro-health benefits. Dietary composition of garlic includes carbohydrates, proteins, dietary fibers, amino acids, fat, vitamins, minerals and water [6,7]. Besides these, garlic also contains various organosulfur compounds like allicin, ajoene, diallyl disulfides (DADS), diallyl trisulfides (DATS), allyl methyl trisulfides and S-methyl cysteine (alliin), which 
not only give characteristic pungent smell to it, but are also responsible for most of the beneficial effects associated with the consumption of garlic [8]. Many experiments and clinical studies have shown anti-microbial, anti-inflammatory, anti-oxidant, hypolipidemic, hypoglycemic and immunomodulatory effects of garlic [7,9-12]. Oral administration of raw garlic in high-fat diet (HFD)-induced obese mice and rats has been reported to prevent weight gain, epididymal fat accumulation and hyperlipidemia [13-15]. Processed garlic such as methanolic extract, garlic powder and garlic oil also have the potential to combat obesity $[14,16,17]$.

Allicin, one of the bioactive components of garlic has numerous biological functions including anti-obesity effects. Allicin administration enhances beiging/ browning of white adipose tissue, modulates gut microbiota and recently has been found to enhance whole-body energy metabolism via brown adipose tissue (BAT) activation $[18,19]$. Allicin is absent in the raw garlic and is only produced upon crushing of the garlic clove from its odorless precursor alliin through the enzymatic reaction of enzyme alliinase [20]. Allicin has very reactive thiol groups, immediately converting or degrading it into diallyl disulfides in the presence of air [21]. Aqueous extract of garlic, however, if stored at lower temperature, has stable allicin [22]. Recently, it has been shown that higher doses of allicin $(500 \mu \mathrm{M})$ induce autophagy and mitophagy in cultured BAT adipocytes and excessive garlic intake could impair BAT functions [19]. Earlier studies suggested protective effects of allicin in high-fat diet-induced complications at relatively higher doses such as 50, 100 and $200 \mathrm{mg} /$ $\mathrm{kg} /$ day [23] and $100 \mathrm{mg} / \mathrm{kg} /$ day [18], therefore we tried to evaluate the preventive effects of allicin-rich garlic extract at lower dose ( $2 \mathrm{mg} / \mathrm{kg} /$ day) in present study. Transient receptor potential ankyrin (TRPA1) is a calcium ion channel, primarily known for its role in pain sensation. This channel has been investigated for other physiological roles in the gastrointestinal tract including gastric motility, satiety and insulin secretion from the pancreas [24-26]. Allicin is a potent agonist of the TRPA1 [27], providing a new direction for the gastromodulatory effects of garlic extract via TRPA1 activation.

Despite available literature on anti-obesity effects of garlic, there are no previously published reports regarding the nutrigenomic effects of freshly prepared allicin-rich garlic extract in HFD-induced obesity. Therefore, the present study was designed to study the multiple tissue-specific nutrigenomic effects of aqueous allicin-rich garlic extract (ARGE) prepared from fresh garlic against HFD-induced changes in rats.

\section{MATERIAL AND METHODS}

\section{Preparation of ARGE}

ARGE was prepared freshly using a previously standardized protocol [28]. Briefly, garlic cloves were washed, peeled and squeezed through kitchen garlic press. Phosphate buffer saline (PBS) was then added to the garlic paste in a ratio of $500 \mu \mathrm{PBS}$ to $1 \mathrm{~g}$ of garlic paste. This mixture was then incubated at $4{ }^{\circ} \mathrm{C}$ for $30-$ 40 min with continuous agitation followed by centrifugation at $6000 \mathrm{rpm}$ for $10 \mathrm{~min}$ at $4{ }^{\circ} \mathrm{C}$. Supernatant was discarded and pellet was re-centrifuged at 13,000 rpm for 15 min at $4{ }^{\circ} \mathrm{C}$. The clear supernatant was collected, filtered and used for high performance liquid chromatography (HPLC) analysis and biological evaluation.

\section{Quantification of Allicin in ARGE using HPLC}

Allicin was synthesized according to previously published article [29]. Briefly, diallyl sulphide (80\%; Sigma Aldrich Chemical Co, MO, USA), was oxidized with hydrogen peroxide in acidic medium at $0{ }^{\circ} \mathrm{C}$. The reaction was neutralized by adding $1 \%$ sodium bicarbonate and was partitioned with dichloromethane to isolate the crude mixture in organic phase. The allicin was isolated from the crude reaction mixture using preparative thin layer chromatography. HPLC analysis was performed to determine the purity of synthesized allicin and its quantification in ARGE. Waters 600 liquid chromatography equipped with Waters 2998 photodiode array (PDA) detector and $\mathrm{C}_{18}$ column $(250 \mathrm{~mm} \times 4.6 \mathrm{~mm}, 60$ $\AA ̊$, $5.0 \mu \mathrm{m}$, Waters Sunfire ${ }^{\circledR}$ ) was used for HPLC. The mobile phase consisted of solvent $A$, methanol and solvent $B$, water. Isocratic HPLC program was as follows: $\mathrm{MeOH}:$ Water, 1:1 for $20 \mathrm{~min}$. The flow rate was $1 \mathrm{ml} /$ min. All the experiments were performed in triplicate. Nuclear magnetic resonance (NMR) and Mass spectroscopic techniques were performed to characterize the synthesized and purified allicin. $1 \mathrm{mg} / \mathrm{ml}$ solution of allicin in methanol was used for MS spectrometry and 10 mg of purified allicin was dissolved in $600 \mu \mathrm{l}$ of $\mathrm{CDCl}_{3}$ to acquire NMR data. For stabilization studies, ARGE was lyophilized immediately after its preparation and then stored at different temperature conditions $\left(-80^{\circ} \mathrm{C}, 4^{\circ} \mathrm{C}\right.$ and room temperature (RT) for varying time period), followed by HPLC analysis for determination of allicin in ARGE using same conditions as mentioned above.

\section{Analysis of total phenolic content}

The total phenolic content of ARGE was estimated spectrophotometrically using Folin-Ciocalteu reagent and gallic acid as standard [30]. Briefly, $100 \mu \mathrm{l}$ of ARGE was mixed with $2.5 \mathrm{ml}$ of Folin-Ciocalteu reagent $(0.2$ $\mathrm{N})$, followed by addition of $2 \mathrm{ml}$ of sodium carbonate solution $(75 \mathrm{~g} / \mathrm{l})$. The reaction mixture was incubated for 120 min in dark conditions and optical density was 
measured at $760 \mathrm{~nm}$ (SpectraMax i3x, Molecular Devices, USA). Results were expressed as Gallic acid equivalents (GAE), in $\mu \mathrm{g}$ per $\mathrm{ml}$ of the sample.

\section{Animals}

Male Sprague-Dawley (SD) rats (6-8 weeks old) were procured from IMTech Center for Animal resources and Experimentation (iCARE), Chandigarh, India. Rats were housed in Animal Experimentation facility (AEF) at National Agri-food Biotechnology Institute (NABI), Mohali, India and kept in a pathogen-free environment at $25 \pm 2{ }^{\circ} \mathrm{C}$, with $12 \mathrm{~h}$ light-dark cycle. All the rats had free access to food and water. All animal experiments were approved by Institutional Animal Ethics Committee (IAEC), NABI (approval no. NABI/2039/CPCSEA/ IAEC/2019/12) and experiments were performed according to the guidelines of Committee for the Purpose of Control and Supervision on Experiments on Rats (CPCSEA) guidelines.

\section{Diets and Interventions}

Normal pellet diet (NPD) was purchased from Hylasco Biotechnology Pvt. Ltd., Hyderabad, India. HFD was prepared in-house using standard composition with slight modifications. Composition of HFD used was: NPD (36.5\%), lard (35\%; local market, Chandigarh, India), casein (25\%; Loba Chemie, Mumbai, India), vitamin and mineral mix (6\%; Virbac Animal Health India, Mumbai, India); DL-methionine (0.3\%; Himedia Laboratories Pvt. Ltd., Mumbai, India); and sodium chloride (0.1\%; Sigma-Aldrich, Saint Louis, MO).

After 1 week of acclimatization, animals were divided into following groups using weight-based randomization: control group $(n=4)$ fed with NPD, HFD group $(\mathrm{n}=4)$ fed with HFD, HFD+ARGE $(2 \mathrm{mg} / \mathrm{kg} /$ day p.o. ( $2 \mathrm{mg} / \mathrm{kg} /$ day allicin) $+\mathrm{HFD} ; \mathrm{n}=4$ ) and ARGE group (2 $\mathrm{mg} / \mathrm{kg} /$ day p.o. $(\sim 2 \mathrm{mg} / \mathrm{kg} /$ day allicin $)+N P D ; n=4)$. Animal body weights were recorded weekly.

\section{Oral glucose tolerance test (OGTT)}

Rats have fasted overnight (12 hours) before oral administration of glucose $(2 \mathrm{~g} / \mathrm{kg}$ body weight) during 14th week of study. Blood glucose concentrations were measured using tail snip method at 0 (before treatment), 30, 60, 90 and 120 minutes after glucose or sodium pyruvate administration using Glucocard (Arkray Factory Inc., Shiga, Japan).

\section{Intraperitoneal pyruvate tolerance test (IPPTT)}

Rats were fasted overnight (12 hours) before intraperitoneal injection of sodium pyruvate $(1 \mathrm{~g} / \mathrm{kg}$ body weight) during 15th week of study. Blood glucose concentrations were measured using tail snip method at 0 (before treatment), 30, 60, 90 and 120 minutes after glucose or sodium pyruvate administration using Glucocard (Arkray Factory Inc., Shiga, Japan).

\section{Insulin tolerance test (ITT) and assessment of insulin resistance}

During the 16th week of the study, overnight fasted rats were intraperitoneally injected with human recombinant insulin $(0.5 \mathrm{IU} / \mathrm{kg}$ body weight). Blood glucose concentrations were measured using tail snip method at 0 (before treatment), 30, 60, 90 and 120 minutes after insulin administration using Glucocard (Arkray Factory Inc., Shiga, Japan). Further, Insulin resistance was calculated using Homeostasis Model Assessment Insulin Resistance (HOMA-IR) using basal glucose (mmol/l) and fasted serum insulin level ( $\mu \mathrm{IU} /$ $\mathrm{ml}$ ) and insulin sensitivity was assessed by using Quantitative insulin sensitivity check index (QUICKI).

\section{Glucose-stimulated insulin release}

Rats were fasted for 12 hours, followed by withdrawal of blood in fasted conditions. Glucose was given orally ( $2 \mathrm{~g} / \mathrm{kg}$ p.o.) to the fasted rats. After $30 \mathrm{~min}$ of glucose administration, blood was withdrawn from rats. Serum was separated and stored at $-80^{\circ} \mathrm{C}$ until further analysis of insulin levels using ELISA (Ray Biotech, Norcross, GA, USA).

\section{Estimation of serum ghrelin levels}

Rats were fasted for 12 hours (dark cycle) followed by collection of blood samples. Blood was allowed to clot for at least 30 minutes before centrifugation at 2000 rpm for 20 minutes. Serum was collected and stored at $-80^{\circ} \mathrm{C}$ until further analysis of fasted serum ghrelin using ELISA (Ray Biotech, Norcross, GA, USA).

\section{Histological Analysis}

After animal sacrifice, visceral white adipose tissue (vWAT) and liver were stored in 10\% v/v buffered formalin for further processing. Small pieces of these tissues were then serially dehydrated using ethanol $(25 \%$, $50 \%, 75 \%, 90 \%$ and $100 \%$ for $2 \mathrm{~h}$ each) after which tissues were processed in xylene for $2 \mathrm{~h}$ (twice) followed by paraffin embedding for $2 \mathrm{~h}\left(60^{\circ} \mathrm{C}\right)$. Tissue sections of $5 \mu \mathrm{m}$ were used for H\&E staining. Briefly, sections were de-paraffinized using xylene (2 min, twice), followed by rehydration using ethanol ( $100 \%$ to $25 \%$, 2 min each). Tissue sections were then stained in Hematoxylin and Eosin (Hi-media Laboratories, Mumbai, India) for $2 \mathrm{~min}$ and $30 \mathrm{sec}$, respectively, washed thrice in PBS. Tissue sections were again serially dehydrated in ethanol and treated in xylene before mounting for microscopic analysis. Images were captured using Leica microscope and analyzed using ImageScope (version 12.1.0.5029, Aperio Technologies Inc). 


\section{RNA extraction and gene expression analysis}

All the tissues (stomach, ileum, colon, liver, hypothalamus, vWAT, and BAT were excised during sacrifice and immediately stored in RNA later (Sigma-Aldrich, USA) for the gene expression analysis. RNA was extracted from tissues using Trizol-Chloroform-Isopropanol method. Briefly, tissues were homogenized in Trizol, followed by chloroform-based phase separation using high-speed centrifugation (12000 rpm, $15 \mathrm{~min}$ at $4^{\circ} \mathrm{C}$ ). RNA was then precipitated using chilled isopropanol (centrifugation: $12000 \mathrm{rpm}, 15 \mathrm{~min}$ at $4{ }^{\circ} \mathrm{C}$ ) and RNA pellet was washed with chilled $75 \%$ ethanol (centrifugation: $12000 \mathrm{rpm}, 15 \mathrm{~min}$ at $4{ }^{\circ} \mathrm{C}$ ). RNA pellet was eluted in nuclease-free water. Qualitative analysis was done using $1.2 \%$ agarose gel electrophoresis to check the integrity of RNA bands. Total RNA quantification was done using Nanodrop at 260/280 nm and cDNA was synthesized using revert-aid first strand cDNA synthesis kit (Themo Fisher Scientific, USA). Gene expression analysis was performed using quantitative Realtime PCR (qPCR) employing iTaq Universal SYBR Green Supermix (Bio-Rad, California, United States). qPCR was performed on CFX96 Touch Real-Time PCR Detection System (BioRad) under following conditions: initial denaturation $-95^{\circ} \mathrm{C}, 2 \mathrm{~min}$, [denaturation $-95^{\circ} \mathrm{C}, 5 \mathrm{~s}$; annealing/extension $\left.-60^{\circ} \mathrm{C}, 30 \mathrm{~s}\right]$ x 40 cycles, final extension $-60^{\circ} \mathrm{C}, 5 \mathrm{~min}$ and melt curve analysis between $60{ }^{\circ} \mathrm{C}-95^{\circ} \mathrm{C}$ with $0.5^{\circ} \mathrm{C} / 5 \mathrm{~s}$ increment. Data were analyzed using $\Delta \Delta C t$ method [31] and $\beta$-actin was used as a housekeeping gene for normalization. The list of primers used is given in Supplementary Table 1.

\section{Indirect Calorimetry}

Total energy expenditure, respiratory quotient, spontaneous physical movement and feed intake was measured using calorimetric cages simultaneously. All the rats were acclimatized for these cages equipped with commercially available grid panels for at least 24 hours before the actual measurements. After acclimatization, 24 hours (12 h nocturnal: $12 \mathrm{~h}$ day time) data were recorded using OxyletPro ${ }^{T M}$ System (Panlab, Harvard Apparatus, Spain) and analyzed using Panlab Metabolism software. Rats were housed individually in these chambers.

\section{Statistical Analysis}

All the values are expressed as mean \pm SEM. Data was analyzed using GraphPad Prism Software (GraphPad, San Diego, California, USA). Multiple groups' comparison was done using One-way or Two-way ANOVA followed by specific post-hoc tests. $P \leq 0.05$ was considered statistically significant. Specific statistical tests used are mentioned in each figure legends.

\section{RESULTS}

\section{Chemical characterization of Allicin in ARGE}

NMR and Mass spectroscopy (Electron spray ionization) were performed to characterize the purified allicin. $1 \mathrm{mg} / \mathrm{ml}$ solution of allicin in methanol was used for MS spectrometry and $10 \mathrm{mg}$ of purified allicin was dissolved in $600 \mu \mathrm{l}$ of $\mathrm{CDCl}_{3}$ to acquire NMR data. The structural data obtained were as follows: ${ }^{1} \mathrm{H}$ NMR $\left(\mathrm{CDCl}_{3}, 400 \mathrm{MHz}\right): \delta$ (ppm) $3.72-3.90\left(\mathrm{~m}, 4 \mathrm{H},-\mathrm{CH}_{2}-\right)$, 5.20 - $5.84\left(\mathrm{~m}, 4 \mathrm{H}, \mathrm{CH}_{2}=\right), 5.89-6.01(\mathrm{~m}, 2 \mathrm{H},=\mathrm{CH}-) ;{ }^{13} \mathrm{C}$ NMR (CDCl, $100 \mathrm{MHz}): \delta$ (ppm) 35.02 (3b, SCH2CH), 59.86 (3a, CHCH2SO), 119.06 (1b, $\mathrm{CHCH}_{2}$ ), 124.02 (1a, $\left.\mathrm{CH}_{2} \mathrm{CH}\right), 125.82$ (2b, $\left.\mathrm{CH}_{2} \mathrm{CHCH}_{2}\right), 132.89$ (2a, $\left.\mathrm{CH}_{2} \mathrm{CHCH}_{2}\right)$ (Figure 1 A, B). MS (ESI) calc. for $\left(\mathrm{C}_{6} \mathrm{H}_{10} \mathrm{OS}_{2}\right)[\mathrm{M}+\mathrm{Na}]^{+}$ 185.26 , found $m / z=185.92$ (Figure 1C). The spectral data was compared with the reported literature and confirmed as allicin [29]. HPLC chromatogram of synthesized allicin depicted the presence of single peak at retention time $9.77 \mathrm{~min}$ (Figure 1D) with purity of 97.19\%. Further, HPLC profile of ARGE depicted the presence of allicin at Rt. 9.77 min (Figure 1D) which was confirmed by peak spiking with pure allicin and it was estimated that ARGE contained $1.96 \pm 0.01 \mathrm{mg} /$ $\mathrm{ml}$ allicin (Figure 1D). ARGE was lyophilized to assess the stability of allicin at different time intervals and temperature conditions. HPLC analysis of lyophilized extract kept at $-80{ }^{\circ} \mathrm{C}$ showed the highest stability of allicin (Figure 1E and 1F). Garlic contains numerous polyphenols, responsible for high antioxidant properties of garlic. Therefore, total phenolic content (Figure 1G) was measured in ARGE using Folin-Ciocalteu method. ARGE contained $66.84 \pm 0.215 \mu \mathrm{g} / \mathrm{ml}$ total phenolic content.

\section{Chronic administration of Allicin-rich garlic extract prevents HFD-induced weight gain, adiposity and improves glucose homeostasis}

Coadministration of HFD with ARGE for 16 weeks prevented HFD-induced weight gain in rats (Figure $\mathbf{2 A}$ ). ARGE administration also prevented diet-induced increase in visceral fat mass (Figure 2B). Histological examination of visceral fat using $\mathrm{H} \& \mathrm{E}$ staining showed that ARGE could prevent diet-induced adipocyte hypertrophy (Figure $\mathbf{2 C}$ ). Digital image analysis also supported the above data of adipocyte hypertrophy in HFD-fed animals (Figure 2D). HFD feeding increased the distribution frequency of larger adipocytes in rats, which were less when ARGE was coadministered to the animals (Figure 2E).

To determine the effects of ARGE on whole-body metabolism, indirect calorimetry was measured. Total activity in all groups showed a clear circadian rhythm, with higher activity during the nocturnal phase (Fig- 
A.

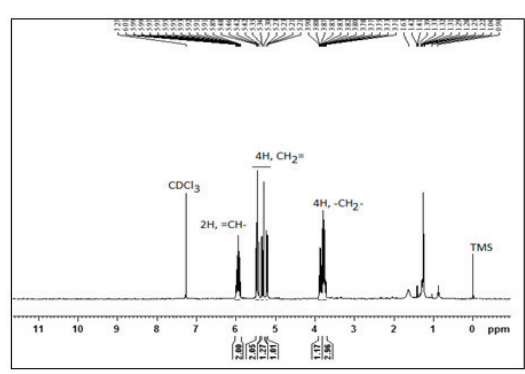

B.

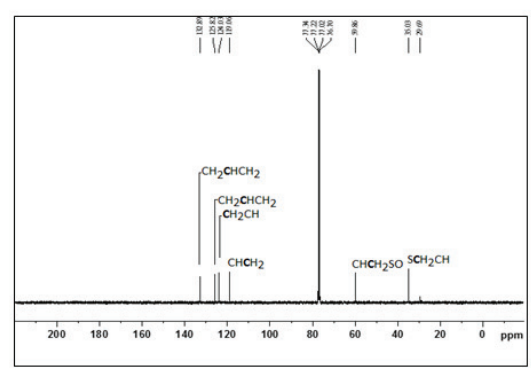

C.

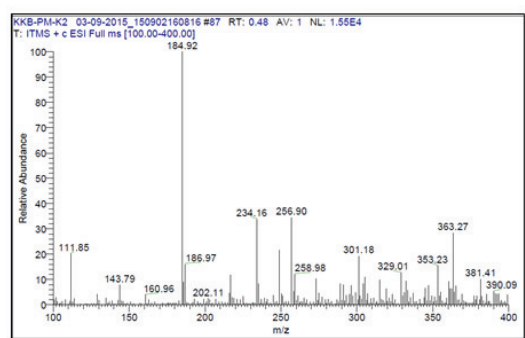

D.

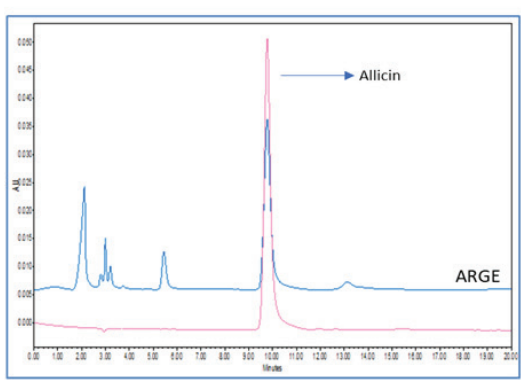

E.

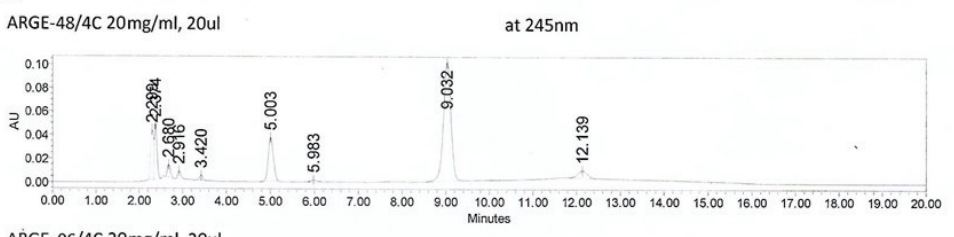

ARGE- $96 / 4 C 20 \mathrm{mg} / \mathrm{ml}$, 20ul

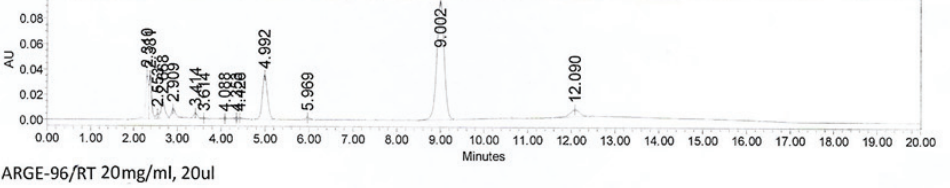
ARGE-96/RT $20 \mathrm{mg} / \mathrm{ml}$, 20ul

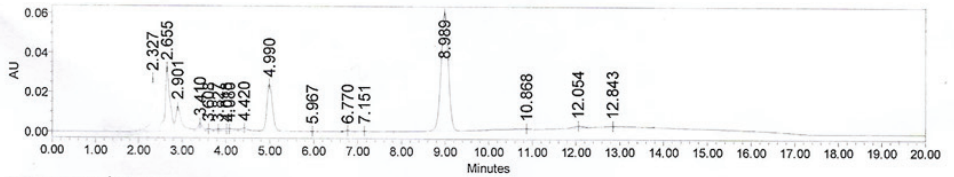
ARGE- $20 \mathrm{mg} / \mathrm{ml}$, 20ul

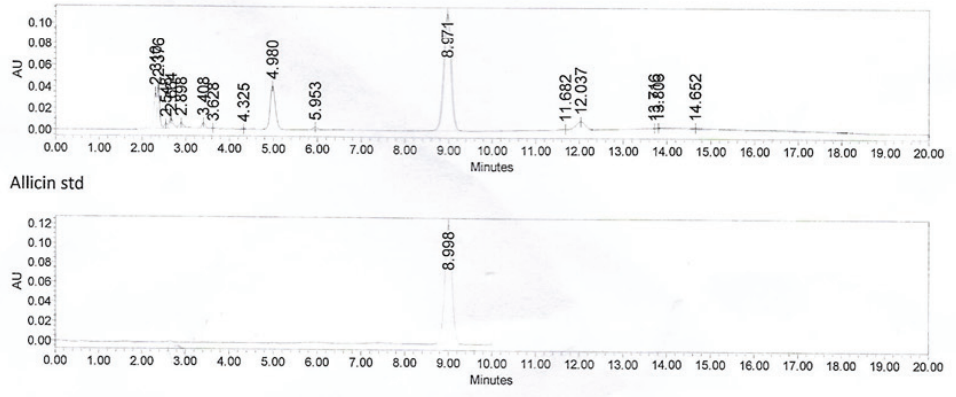

F.

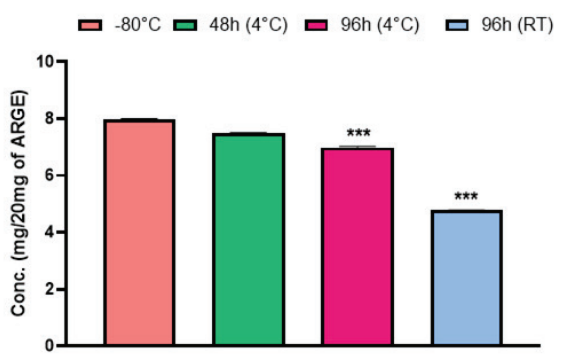

G.

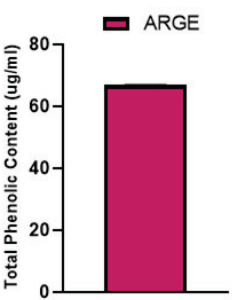

Figure 1. Quantification of Allicin in ARGE. (A) Proton NMR (H' - NMR) of pure allicin, (B) Proton NMR (C13 - NMR) of pure allicin, (C) Mass spectra of pure allicin, (D) Overlay HPLC chromatogram of allicin and ARGE, (E) Stability characterization of allicin in ARGE, (F) Allicin quantification in ARGE at different time intervals and temperature conditions, (G) Total phenolic content. Data have been represented as Mean \pm SEM. Analysis was carried out using One-Way ANOVA followed by Tukey's multiple comparison test. ${ }^{*} \mathrm{p}<0.05$ versus samples stored at $-80^{\circ} \mathrm{C},{ }^{* *} \mathrm{p}<0.01$ versus samples stored at $-80^{\circ} \mathrm{C},{ }^{* * *} \mathrm{p}<.001$ versus samples stored at $-80^{\circ} \mathrm{C}$.

ure 2F). ARGE administration led to enhanced activity during the daytime (Figure 2F). However, ARGE supplementation does not affect respiratory quotient, total energy expenditure and food intake (Data not shown).

ARGE administration improved glucose clearance as observed in OGTT (Figure 3A). HFD-fed animals showed hyposensitivity towards insulin, as insulininduced drop in blood glucose levels was lower in these animals (Figure 3C). AUC analysis of OGTT and ITT showed high level of blood glucose in HFD-fed animals (Figure 3B and 3D). However, no significant differences in any group were observed in IPTT (Figure 3E and 3F). To further evaluate the effect of ARGE on insulin sensitivity, glucose-stimulated insulin release was measured (Figure 3G). A significantly high level of serum insulin was found in HFD-fed animals in fasted state (Figure 3G), whereas glucose-induced increase in serum insulin concentration was low in HFD-fed animals (Figure $3 \mathbf{H}$ ). Administration of ARGE improved glucose-induced serum insulin levels, suggesting improved insulin sensitivity (Figure $\mathbf{3 G}$ and $\mathbf{3 H}$ ). To evaluate the insulin resistance in HFD-fed rats, QUICKI index and HOMA-IR were calculated. Lower value in QUICKI index and higher HOMA-IR in HFD-fed rats corresponds to insulin resistance (Figure $\mathbf{3 I}$ and $\mathbf{3} \mathbf{J}$ ), and ARGE administration prevented the insulin resistance. 

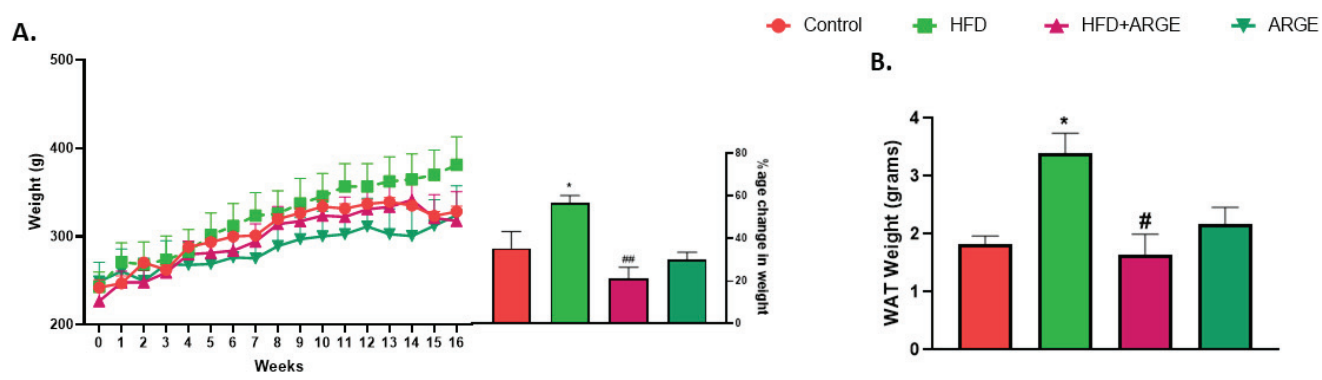

B.

C.
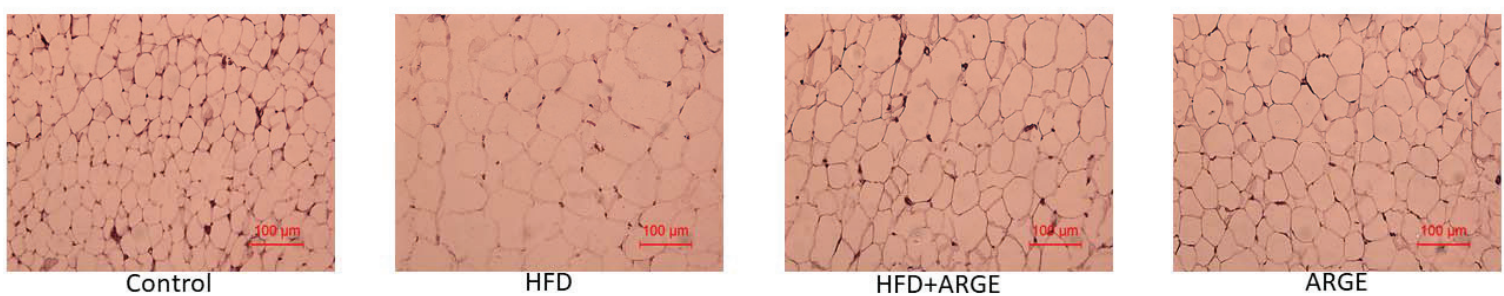

D.

E.

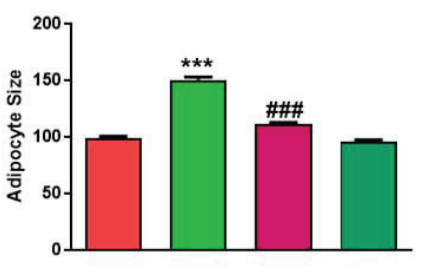

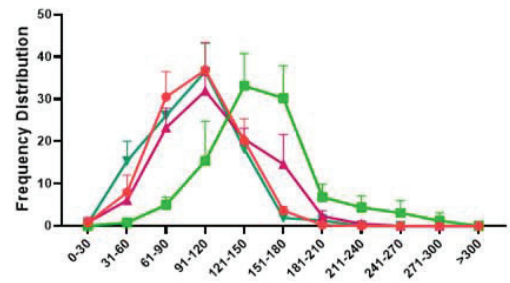

F.

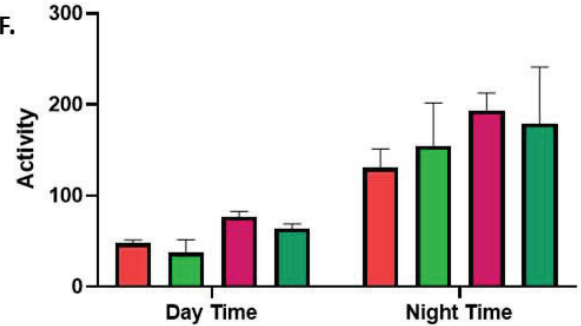

Figure 2. Effect of chronic administration of ARGE on body weight gain and adiposity in HFD-fed rats. Rats were fed either with NPD (control group) or HFD, along with daily oral administration of ARGE (1 ml/kg body weight p.o.; $2 \mathrm{mg} / \mathrm{kg} /$ day allicin) to the HFD + ARGE and ARGE per se group. (A) Weekly body weights and change in body weight gain in 16 weeks $(n=4),(B)$ vWAT mass $(n=4)$, (C) Representative images of hematoxylin and eosin (H\&E) stained sections of vWAT (20X magnification, scale: $100 \mu M, n$ = 3 rats per group, 5 images per group), (D \& E) Adipocytes size and distribution frequency of H\&E stained sections of vWAT, (F) Animals were kept in the metabolic cages for 12 hours during daytime and 12 hours during nighttime for the measurement of different parameters using indirect calorimetry. Total activity during daytime and nighttime is shown. Data have been represented as Mean \pm SEM. Analysis was carried out using One-Way ANOVA followed by Tukey's multiple comparison test and student's unpaired t-test. ${ }^{*} \mathrm{p}<0.05$ versus Control, ${ }^{* *} \mathrm{p}<0.01$ versus Control, ${ }^{* * *} \mathrm{p}<.001$ versus Control; $\# \mathrm{p}<0.05$ versus HFD, \#\#p $<0.001$ versus HFD, \#\#\#p <0.001 versus HFD.

\section{ARGE enhances browning and energy expenditure in vWAT and BAT}

To investigate the effects of ARGE on energy expenditure through WAT, qRT-PCR was performed. Figure 4A represents a heat map showing differential expression of various genes involved in energy expenditure as well as browning in WAT. Supplementation of ARGE to HFD-fed rats significantly increased the expression of several genes including AdipoQ (Adiponectin), TMEM26 (a browning marker on beige preadipocytes), PGC1- $a$ (a key regulator of energy metabolism, mitochondrial biogenesis), PAT2, P2RX5 (markers for beige adipocytes) and TBX1 (Figure 4B). Gene expression analysis was performed to evaluate the effect of ARGE on energy expenditure genes in BAT. The heat map in Figure 5A shows an overview of gene expression of various energy expenditure-related markers in mentioned groups. Since BAT is a metabolically active organ, some of the genes, such as PPARY, COX $8 b$ and SHOX2 were found to be significantly higher in both HFD group and ARGE-treated animals (Figure 5B). Browning markers like TMEM26 and TBX1 were significantly increased in ARGE-supplemented animals (Figure 5B).

\section{ARGE administration prevents HFD-induced ectopic fat deposition in liver}

To determine histopathological changes in liver tissues, Hematoxylin-Eosin staining was performed. We observed that ARGE prevented the HFD-induced lipid accumulation in liver (Figure 6A). We also examined expression pattern of gluconeogenic, glycogen metabolism and key insulin signaling genes. Transcriptional factors controlling lipogenesis and gluconeogenesis, such as FOXO1, ChREBP and fatty acid translocase gene $C D 36$ were increased after HFD feeding (Figure 6B). ARGE supplementation also upregulated the gene expression of these transcriptional factors (Figure 6B). Significantly higher expression levels of CPT1, GYS (gly- 


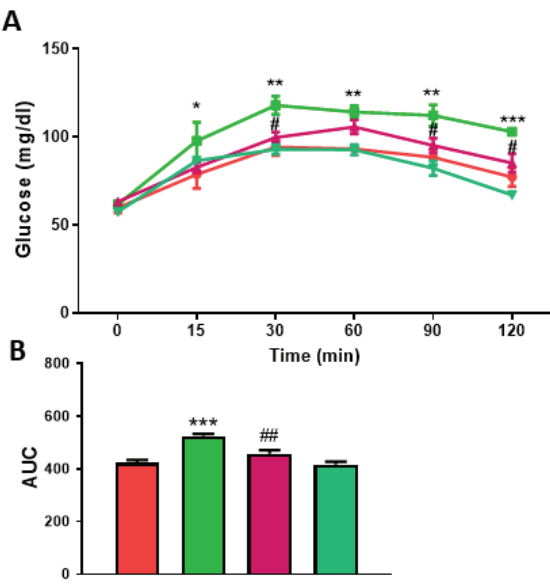

G

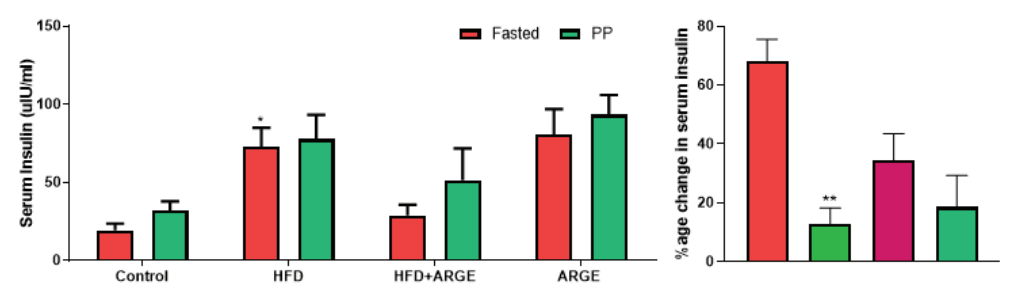

C

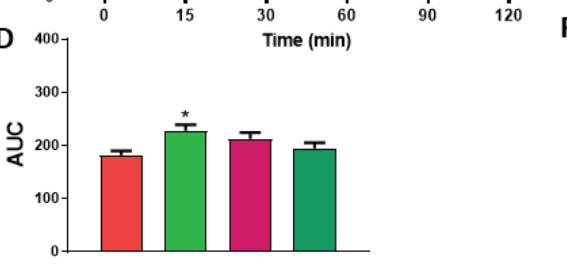

I

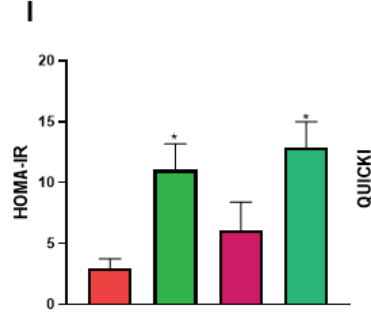

E

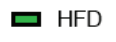

HFD+ARGE

ロ ARGE
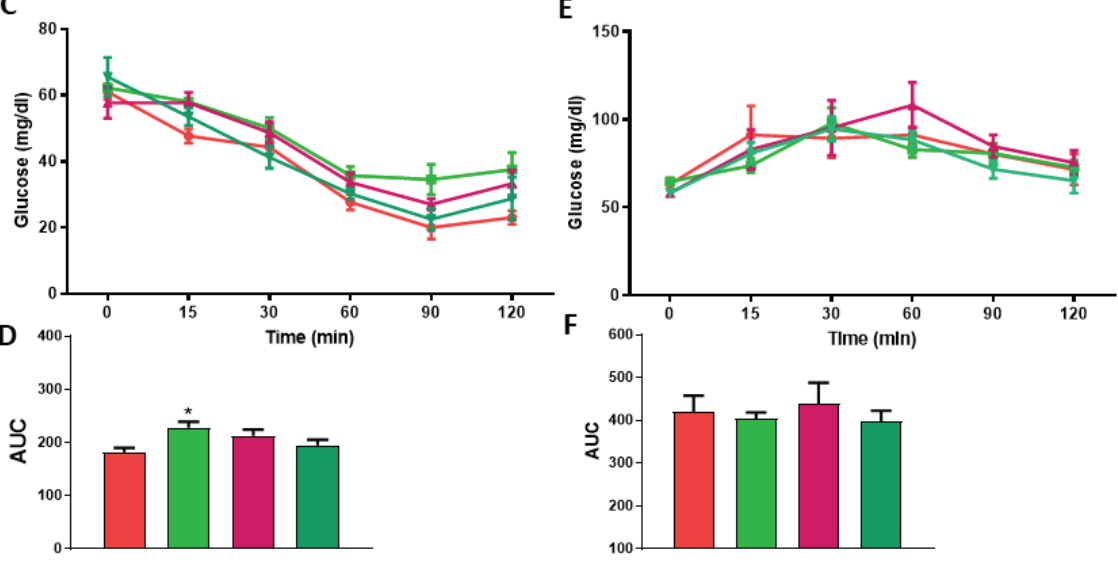

J

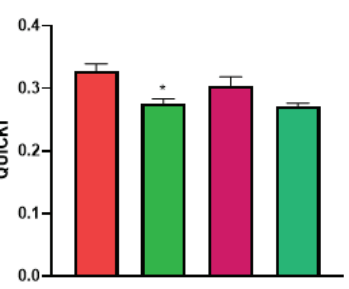

Figure 3. Effect of ARGE on glucose homeostasis and serum insulin levels. Glucose homeostasis tests (OGTT, ITT, IPPTT) were performed during 13-15th week of the study. Animals were fasted for 12 hours, after which dose of $2 \mathrm{~g} / \mathrm{kg}$ body weight p.o. glucose for OGTT, $0.5 \mathrm{lU} / \mathrm{kg}$ body weight i.p. insulin for ITT and $1 \mathrm{~g} / \mathrm{kg}$ body weight i.p. pyruvate for IPPTT were given. Blood glucose levels were measured at 0 (before any treatment), $15 \mathrm{~min}, 30 \mathrm{~min}, 60 \mathrm{~min}, 90 \mathrm{~min}$ and $120 \mathrm{~min}$. (A), (B) and (C) Recorded blood glucose concentrations in OGTT, ITT and IPPTT ( $n=4) ;(D),(E)$ and (F) Area under the concentration curves of OGTT, ITT and IPPTT respectively. For serum insulin level measurement animals were fasted for 12 hours followed by $2 \mathrm{~g} / \mathrm{kg}$ body weight p.o. glucose administration. Blood was collected both in fasted as well as after glucose administration; (G) and (H) Serum insulin concentrations in fasted and glucose treated animals; percentage change in serum insulin levels; (I) and (J) QUICKI and HOMA-IR indexes. Control - Normal pellet diet-fed animals; HFD + ARGE $-1 \mathrm{ml} / \mathrm{kg}$ body weight p.o. ARGE ( $2 \mathrm{mg} / \mathrm{kg} /$ day allicin) to HFD fed animals; PP - $2 \mathrm{~g} / \mathrm{kg}$ body weight p.o. glucose. Data have been represented as Mean \pm SEM. Analysis was carried out using OneWay ANOVA followed by Tukey's multiple comparison test. * $p<0.05$ versus Control, ${ }^{* *} p<0.01$ versus Control, ${ }^{* * *} p<.001$ versus Control; $\# \mathrm{p}<0.05$ versus HFD, \#\# $<0.001$ versus HFD, \#\#\#p $<0.001$ versus HFD.

cogen synthase), GCK1 (glucokinase), ACC (acetyl-coA carboxylase) and UCP2 (uncoupling protein 2) were found in ARGE-treated groups, whereas gene expression of G-6-PC (glucose-6-phosphatase) was significantly downregulated in ARGE group, corresponding to more glycogen synthesis or less circulating glucose (Figure 6C).

\section{ARGE administration regulates expression of hunger and satiety hormones}

Various genes involved in the regulation of gut hormones were evaluated in stomach, ileum and colon using qRT-PCR. Figure 7A represents a heat map showing differential expression of various genes in stomach, ileum and colon. Ghrelin, a hunger hormone, is secreted in stomach. Gene expression analysis showed higher expression of ghrelin in HFD-fed animals, which was reversed by ARGE supplementation (Figure 7B). Higher level of circulating ghrelin was observed in HFD-fed rats (Figure 7B). ARGE supplementation also increases the gene expression of GOAT (ghrelin-o-acyl transfer- ase; processing of pre-proghrelin to ghrelin) and TRPA1 in stomach (Figure 7C). Hormones responsible for satiety, GLP-1 and CCK showed higher gene expression in ARGE-administered animals, however non-significant (Figure 7A). Genes involved in the regulation of secretion of these hormones, CRTC2 and PCSK2 were significantly higher in HFD+ARGE group (Figure 7D). Gene expression of medium-chain and long-chain fatty acid sensors, GPR84 and GPR120 was decreased in HFD-fed animals. TRPA1 expression was significantly higher in ARGE group in ileum (Figure 7D).

\section{ARGE modulates anorexigenic and orexigenic gene expression in hypothalamus}

We investigated the changes in the expression level of anorexigenic genes and their associated receptors in hypothalamus (Figure 7E). A significant reduction in the expression level of anorectic gene, BDNF (Brain derived neurotrophic factor) was observed in HFD-fed animals, which was reversed by ARGE supplementa- 
A.

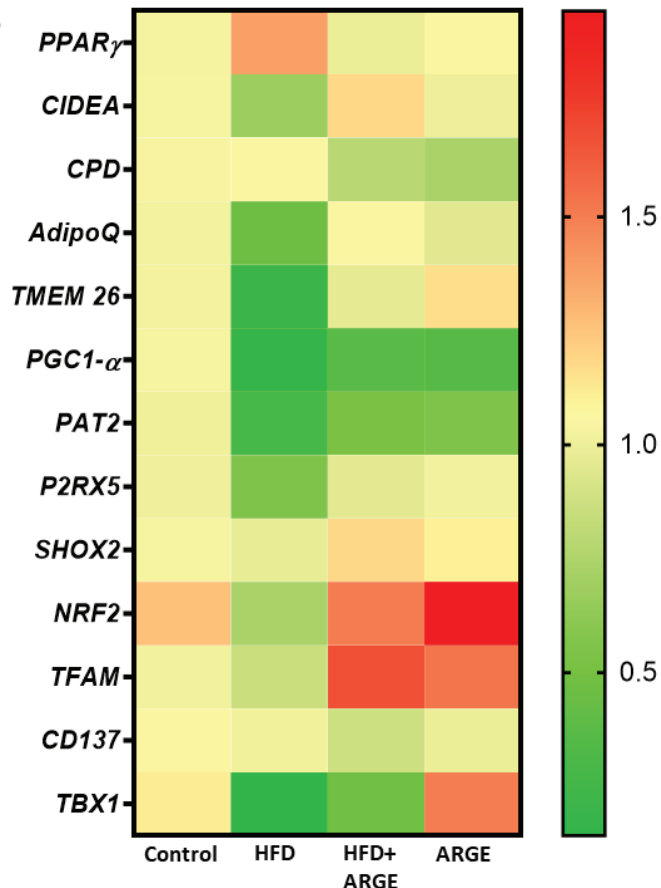

B.
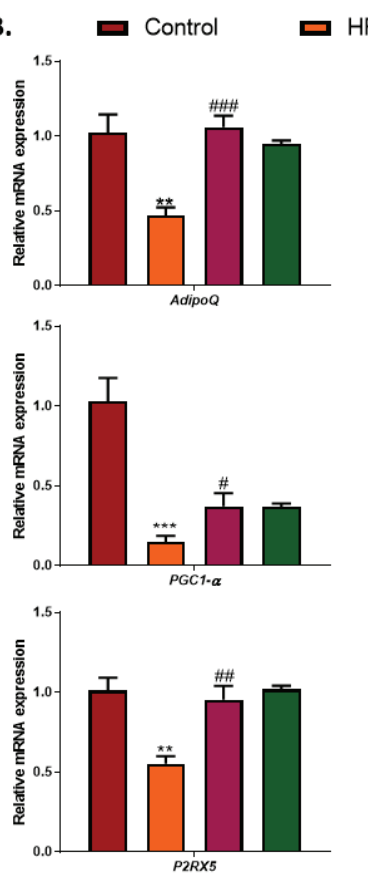
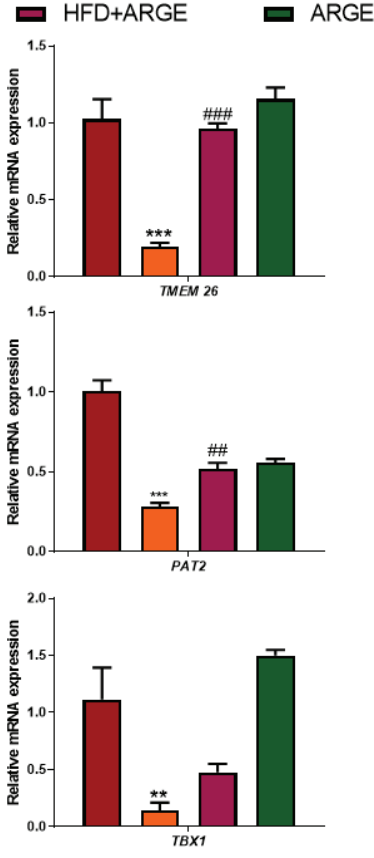

Figure 4. Gene expression analysis of vWAT samples. Rats were fed either with NPD (control group) or HFD, along with daily oral administration of ARGE (1 ml/kg body weight p.o.; $2 \mathrm{mg} / \mathrm{kg} /$ day allicin) to the HFD + ARGE group and ARGE per se group. At the end of the study tissues were collected; RNA was isolated using trizol: chloroform: isopropanol method followed by CDNA synthesis. Quantitative real-time PCR was performed to analyze different genes associated with energy expenditure, browning and related markers. (A) Heat map depicting overview of different genes in VWAT; (B) Genes representing major changes in vWAT related to energy expenditure and browning ( $n=3$ in control group; $n=4$ in other groups). PPAR - peroxisome proliferatoractivated receptor gamma; CIDEA - Cell death-inducing DFFA like effector A; CPD - Carboxypeptidase D; AdipoQ - Adiponectin precursor; TMEM 26 - Transmembrane protein 26; PGC1-a - PPARy coactivator 1 alpha; PAT 2 - p-type cation-transporting ATPase; P2RX5 - Purinergic receptor P2X; SHOX2 - Short stature homeobox 2; NRF2 - Nuclear factor erythroid 2-related factor 2; TFAM Transcription factor A mitochondrial; TBX1 - Tata binding box transcription factor 1. Data have been represented as Mean \pm SEM. Analysis was carried out using One-Way ANOVA followed by Tukey's multiple comparison test. ${ }^{*} p<0.05$ versus Control, ${ }^{* *} p<0.01$ versus Control, ${ }^{* * *} \mathrm{p}<.001$ versus Control; $\# \mathrm{p}<0.05$ versus HFD, \#\# $<0.001$ versus HFD, \#\#\# $<0.001$ versus HFD.

tion. We compared expression levels of two receptors related to the functionality of anorectic and orexigenic genes. There was a significant upregulation of MC4R genes in HFD-fed group, corresponding to the hungerphenotype in these animals which was reversed by ARGE administration. (Figure 7E). We also observed an enhanced expression of InsR (Insulin receptor) (Figure 7E).

\section{DISCUSSION}

Obesity adversely affects almost every physiological function of the body and increases the risk of developing cardiovascular diseases hypertension, type 2 diabetes, hyperlipidemia, several types of cancers, kidney diseases and liver disorders [32]. Garlic is a widely consumed spice throughout the world. It contains a variety of bioactive compounds, such as organosulfur compounds (allicin, DADS, DATS, alliin, SAM), saponins, phenolic compounds and polysaccharides, responsible for the diverse effects of garlic on health [7]. Garlic in different forms has been studied for its anti-obesity and hypolipidemic effects. Garlic oil reduced body weight gain, adipose tissue weight and prevented fatty liver in HFD-fed rats $[14,15]$. Similar effects on body weight gain have been observed with methanolic extract of black garlic in HFD-fed rats [16].

In present study, we employed aqueous allicin-rich garlic extract (ARGE), prepared according to a previously reported method with slight modifications [33]. Allicin has multiple pharmacological functions, including cholesterol-lowering effects [34], browning of WAT [35] and regulates energy homeostasis through BAT activation [19]. Since allicin is a highly reactive volatile compound, it decomposes rapidly in the presence of air. It was shown that aqueous extract of garlic, if stored at lower temperature $\left(-20{ }^{\circ} \mathrm{C}\right.$ or $\left.-80{ }^{\circ} \mathrm{C}\right)$ have more stability of allicin $[22,36]$. HPLC analysis of ARGE showed allicin stability even at $4{ }^{\circ} \mathrm{C}$ for almost 48 hours. Degradation of allicin was much less in aqueous extract when stored at $-80^{\circ} \mathrm{C}$, suggesting higher stability in extract form. Also, presence of polyphenols in ARGE could prevent oxidation of allicin in extract. This allicin-rich garlic extract offers several advantages over other extracts of garlic such as to prepare methodol- 
A.

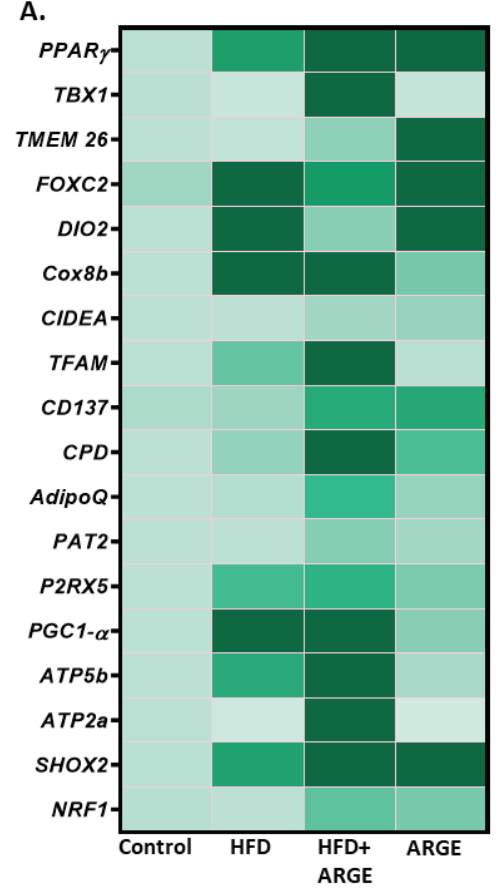

B.
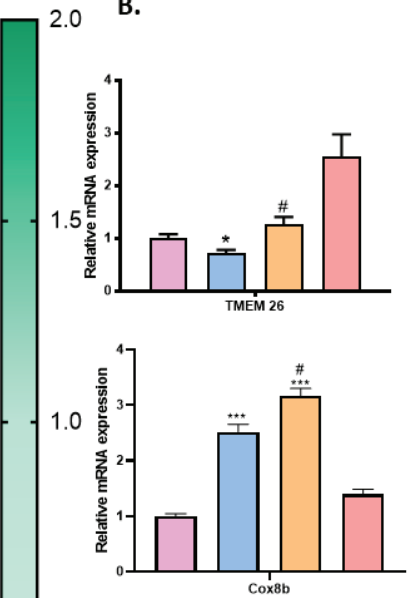

0.5

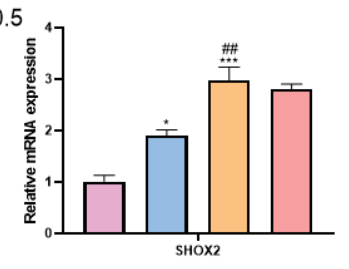

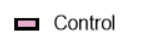

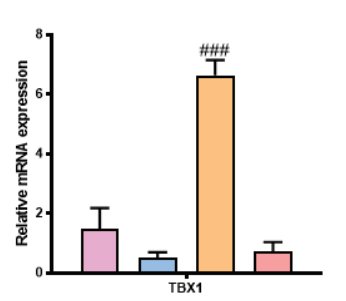

ロ HFD+ARGE ロ ARGE
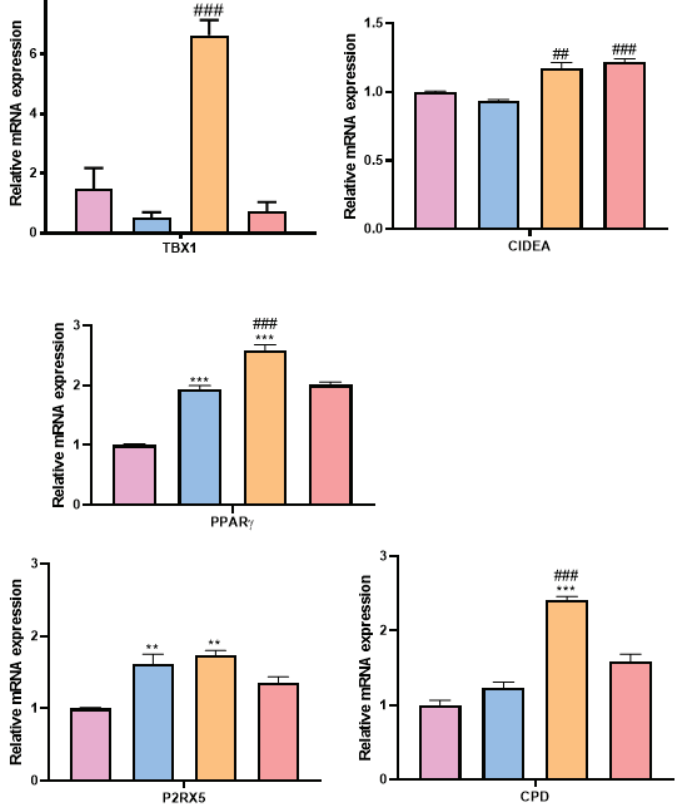

Figure 5. Effect of chronic administration of ARGE on brown adipose tissue (BAT). Rats were fed either with NPD (control group) or HFD, along with daily oral administration of ARGE (1 ml/kg body weight p.o.; $2 \mathrm{mg} / \mathrm{kg} / \mathrm{day}$ allicin) to the HFD + ARGE group and ARGE per se group. At the end of the study tissues were collected; RNA was isolated using trizol:chloroform:isopropanol method followed by CDNA synthesis. Quantitative real-time PCR was performed to analyze different genes associated with energy expenditure, browning and related markers. (A) Heat map depicting overview of different genes in BAT; (B) Genes representing major changes in BAT related to energy expenditure and browning ( $\mathrm{n}=3$ in control group; $\mathrm{n}=4$ in other groups). $P P A R \gamma$ - peroxisome proliferator-activated receptor gamma; CIDEA - Cell death-inducing DFFA like effector A; CPD - Carboxypeptidase D; AdipoQ - Adiponectin precursor; TMEM 26 - Transmembrane protein 26; PGC1-a - PPAR coactivator 1 alpha; PAT 2 - p-type cation-transporting ATPase; P2RX5 - Purinergic receptor P2X; SHOX2 - Short stature homeobox 2; NRF2 - Nuclear factor erythroid 2-related factor 2; TFAM - Transcription factor A mitochondrial; TBX1 - Tata binding box transcription factor 1; FOXC2 - Forkhead box protein C2; DIO2 - lodothyronine deiodinase 2; Cox8b-Cytochrome C oxidase subunit 8B; ATP5b-ATP synthase F1 subunit beta. Data have been represented as Mean \pm SEM. Analysis was carried out using One-Way ANOVA followed by Tukey's multiple comparison test and Two-Way ANOVA followed by Bonferroni's multiple comparisons. ${ }^{*} p<0.05$ versus Control, ${ }^{* *} p<0.01$ versus Control, ${ }^{* *} p<$ .001 versus Control; \#p $<0.05$ versus HFD, \#\#p <0.001 versus HFD, \#\#\#p < 0.001 versus HFD.

ogy as it employs use of PBS and no other chemical, safer to use and higher stability of allicin.

ARGE supplementation prevented HFD-induced weight gain in rats. HFD feeding is also associated with adipocyte hypertrophy [37]. Histological examination revealed larger adipocytes and increased visceral adipose tissue mass in HFD-fed rats, which were attenuated by chronic supplementation of ARGE. In liver, ARGE supplementation attenuated HFD-induced ectopic fat accumulation as observed in histology, however in gene expression analysis for lipid metabolism, we did not find any significant changes. WAT, majorly responsible for energy storage in the body, could be stimulated to undergo browning or "beiging", which effectively enhances energy expenditure and prevents the development of obesity [38]. Browning of WAT is regulated by multiple transcription factors and signaling pathways. Garlic consumption has been reported to stimulate thermogenesis and decrease adipogenesis in WAT [39]. In present study, RT-PCR analysis of thermogenic genes and their transcriptional factors suggested induction of brite type phenotype in ARGE supplemented group. ADIPOQ gene provides instruction for the synthesis of hormone adiponectin, a hormone exclusively synthesized by white adipocytes which stimulates fat burning and glucose utilization in liver and muscle cells [40]. A significantly higher expression of $A D I P O Q$ gene after ARGE supplementation was observed. BAT is involved in the thermogenesis and regulation of energy expenditure [41]. Chronic consumption of HFD increased the gene expression of transcription factor PPARY, PGC1-a (responsible for mitochondrial biogenesis) and mitochondrial enzyme COX8b, possibly due to diet-induced thermogenesis. Since BAT is involved in excessive fat combustion in the body, chronic HFD feeding could activate a compensatory mechanism to counter excess energy consumed $[42,43]$. ARGE supplementation further increased the expression of browning-related mitochondrial biogenesis and energy expenditure genes (TMEM26, TBX1, Cl$D E A, S H O X 2, P P A R Y, P 2 R X 5)$ as compared to HFD group.

HFD feeding is well-known inducer of peripheral insulin resistance, a progressive reduction in the responsiveness of the peripheral organs to the insulin [44]. 


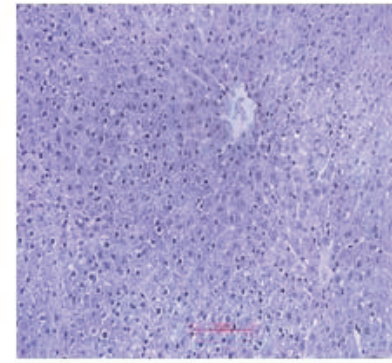

Control

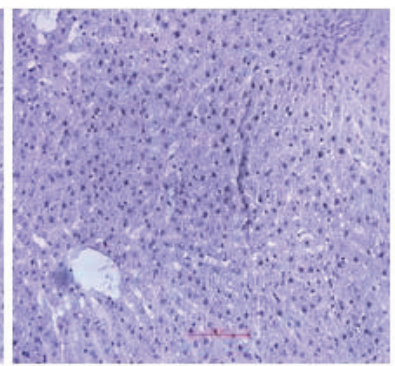

HFD

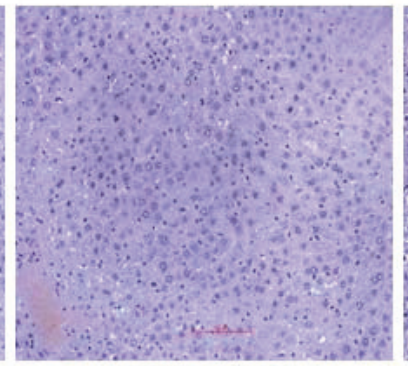

HFD+ARGE

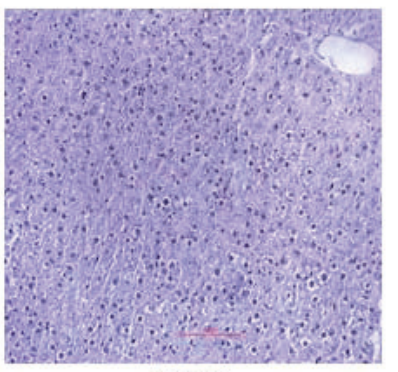

ARGE

B
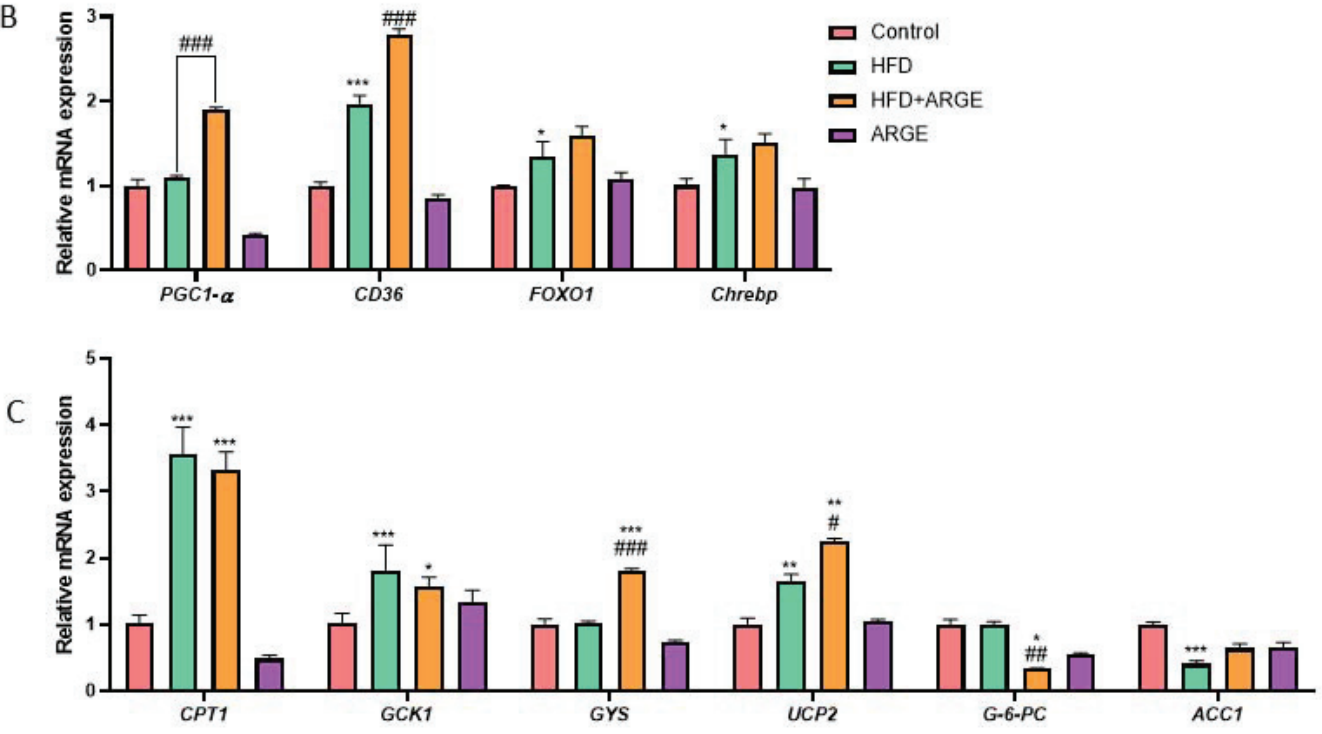

Figure 6. Effect of chronic administration of ARGE on liver. Rats were fed either with NPD (control group) or HFD, along with daily oral administration of ARGE (1 ml/kg body weight p.o.; $2 \mathrm{mg} / \mathrm{kg} /$ day allicin) to the HFD + ARGE group and ARGE per se group. (A) Representative images of $\mathrm{H} \& \mathrm{E}$ stained sections of liver tissues (20X magnification, scale: $100 \mu \mathrm{M}$ ); (B-C) Gene expression analysis of gluconeogenesis and glycogen metabolism in liver. Data have been represented as Mean $\pm \mathrm{SEM}$. Analysis was carried out using One-Way ANOVA followed by Tukey's multiple comparison test. ${ }^{*} p<0.05$ versus Control, ${ }^{* *} p<0.01$ versus Control, ${ }^{* * *} p<.001$ versus Control; $\# p<0.05$ versus HFD, \#\#p < 0.001 versus HFD, \#\#\# < 0.001 versus HFD.

Oral administration of raw garlic improves insulin sensitivity in fructose-fed diabetic rats [45]. Higher serum insulin, and assessment of HOMA-IR and QUICKI indicated a state of hyperinsulinemia and systemic insulin resistance in HFD group. OGTT also reflected higher blood glucose levels in HFD-fed animals. ARGE supplementation prevented HFD-induced insulin resistance and improved glucose homeostasis. Also, gene expression analysis for glycogen metabolism in liver showed an upregulated level of GYS2, a rate-limiting enzyme in the synthesis of glycogen in the liver. On the other hand, glucose-6-phosphatase (G-6-PC), which catabolizes glycogen into glucose was found to be lower at gene level in ARGE supplemented group. These observations suggested that ARGE improved overall glucose homeostasis.

The gastrointestinal tract not only absorbs dietary nutrients but also controls total dietary intake. Several hormones secreted by parts of gastrointestinal tract, ghrelin, CCK, PYY, GLP-1 and GIP, play a vital role in maintaining energy homeostasis and body weight regulation [46]. Ghrelin is the only known orexigenic or hunger hormone secreted by stomach. Several studies have reported ghrelin as a potent appetite stimulator $[47,48]$. Gene expression of ghrelin, as well as total ghrelin levels were drastically enhanced in HFDfed rats whereas ARGE supplementation reversed the same. Further, ARGE administration altered the gene expression of satiety hormones such as GLP-1 and CCK in ileum, with little or no effect in colon. Gene expression of PCSK2 and CRTC2 (genes involved in the synthesis and exocytosis of gut hormones) was significantly upregulated after ARGE supplementation. Hypothalamus is involved in the central control of feeding and energy expenditure [49]. Two distinct antagonistic populations of neurons i.e., NPY/AgRP (appetite stimulant) and POMC/CART (appetite suppressant) in hypothalamus and their receptors collectively regulate dietary intake [49]. We observed that gene expression of orexigenic hormones, NPY/AgRP remained unaffected in ARGE supplemented group (data not shown). By contrast, gene expression of satiety hormones BDNF 


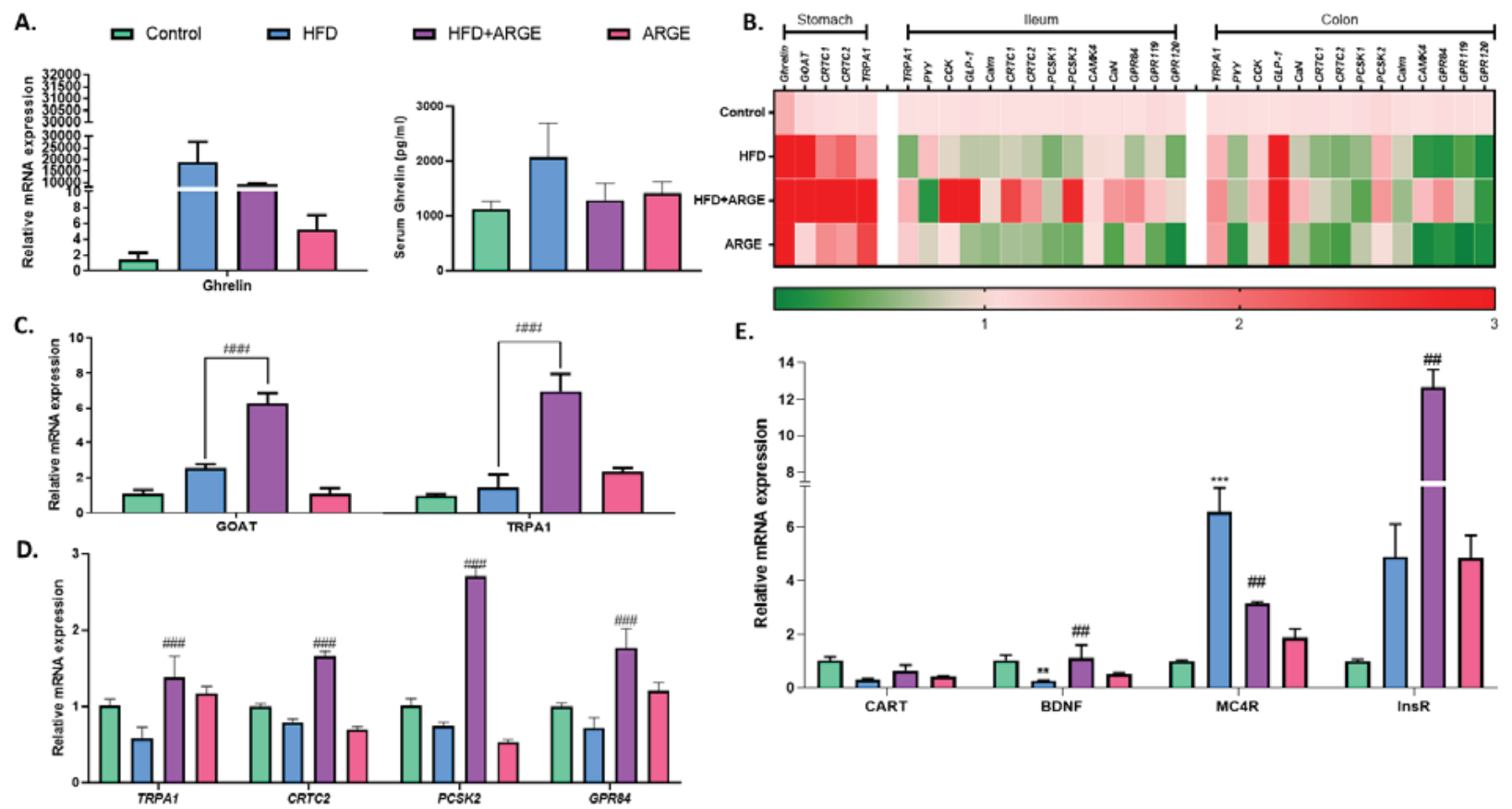

Figure 7. Effects of chronic administration of ARGE on gene expression in the gastrointestinal tract and hypothalamus. Rats were fed either with NPD (control group) or HFD, along with daily oral administration of ARGE (1 ml $/ \mathrm{kg}$ body weight p.o. $\sim 2 \mathrm{mg} / \mathrm{kg} /$ day allicin) to the HFD + ARGE group and ARGE per se group. At the end of the study tissues were collected; RNA was isolated using trizol:chloroform:isopropanol method followed by CDNA synthesis. Quantitative real-time PCR was performed to analyze different genes associated with maintaining hunger and satiety in the gastrointestinal tract. (A) Gene expression and serum concentration of ghrelin in stomach; (B) Heat map depicting overview of different genes in stomach, ileum and colon; (C) Gene expression of GOAT and TRPA 1 in stomach; (D) Genes with major changes in ileum ( $\mathrm{n}=3$ in control group; $\mathrm{n}=4$ in other groups); (E) Gene expression of anorexigenic hormones and their associated receptors in hypothalamus. GOAT - Ghrelin O-acetyl transferase; $C R T C 1$ - CREB regulated transcription co-activator 1; $P Y Y$ - peptide YY; CCK-Cholecystokinin; GLP-1 - Glucagon-like peptide 1; Calm - calmodulin; PCSK1 - proconvertase 1; CAMK4 - Calcium/Calmodulin dependent protein kinase 4; CaN - calcineurin; GPR84 - G-protein coupled receptor; BDNF - Brain-derived neurotrophic factor; CART - Cocaine- and amphetamine-regulated transcript; $M C 4 R$ - Melanocortin 4 receptor; InsR - Insulin receptor. Data have been represented as Mean $\pm \mathrm{SEM}$. Analysis was carried out using One-Way ANOVA followed by Tukey's multiple comparison test. ${ }^{*} p<0.05$ versus Control, ${ }^{* *} p<0.01$ versus Control, ${ }^{* * *} p<$ .001 versus Control; $\# p<0.05$ versus HFD, \#\#p $<0.001$ versus HFD, \#\#\#p $<0.001$ versus HFD.

and CART was significantly higher in HFD + ARGE group. Reduction in the gene expression of BDNF is associated with obesity [50].

TRPA1 (transient receptor potential cation channel subfamily ankyrin, type 1) ion channel has many physiological roles including regulation of gut hormone secretion, gastric motility, insulin secretion etc. other than its primary function in nociception $[24,25,51]$. Since allicin is a known agonist of TRPA1 [28], dietary modulation of TRPA1 could also contribute to the regulation of gut hormones. In present study, gene expression of TRPA 1 in gastrointestinal tract and dorsal root ganglion neurons innervating colon was analyzed. RT-PCR analysis showed significantly higher expression of TRPA1 in stomach and ileum of HFD + ARGE, with no change in colon as compared to HFDfed rats, suggesting a possible role of TRPA1-mediated regulation of ghrelin secretion in ARGE supplemented group. In our study, we did not find any direct effect on energy expenditure after ARGE supplementation. Further studies focusing on gut hormones or protein expressions and molecular mechanism are required to validate gene expression changes.

\section{CONCLUSION}

The present study has shown that ARGE provides an easy and economical method to prepare aqueous garlic extract with stable allicin. Comparable to the previously reported anti-obesity effects of different formulation of garlic, ARGE also reduced weight gain, adipose tissue hypertrophy and liver steatosis. Additionally, nutrigenomic effects of ARGE in browning of WAT, glycogen metabolism, gut hormone secretion and their regulation, provide a novel insight into the nutrigenomic effects of ARGE, which can be exploited in the future as a nutraceutical for prevention of obesity.

\section{ACKNOWLEDGMENT}

Authors would like to thank Department of Biotechnology (DBT), Government of India for providing research grant to National Agri-food Biotechnology Institute (NABI) and Dr. Mahendra Bishnoi, research fellowship to Ms. Neha Mahajan. Authors would like to thank DBTeLibrary Consortium (DelCON) for providing online literature resources. 


\section{AUTHORS' CONTRIBUTION}

$\mathrm{MB}$ and NM designed the experiments. NM, ViK, VK and JK performed the experiments. NM, PK, PM, RV, RM and SJ performed the characterization experiments. NM and $\mathrm{MB}$ did analysis of experiments. NM and ViK wrote the manuscript; MB and KKK reviewed and edited the manuscript.

\section{REFERENCES}

1. Blüher M. Obesity: global epidemiology and pathogenesis. Nat Rev Endocrinol. 2019; 15(5):288-298.

2. Kopelman P. Health risks associated with overweight and obesity. Obes Rev. 2007; Suppl 1:13-7.

3. Chatterjee A, Gerdes MW, Martinez SG. Identification of risk factors associated with obesity and overweight - a machine learning overview. Sensors (Switzerland). 2020; 20(9):2734.

4. Li D, Zhang T, Lu J, Peng C, Lin L. Natural constituents from food sources as therapeutic agents for obesity and metabolic diseases targeting adipose tissue inflammation. Crit Rev Food Sci Nutr. 2020; 1-19.

5. Dragano NRV, Fernø J, Diéguez C, López M, Milbank E. Recent Updates on Obesity Treatments: Available Drugs and Future Directions. Neuroscience. 2020; 437:215239.

6. Szychowski KA, Rybczyńska-Tkaczyk K, Gaweł-Bẹben K, Ašwieca M, Kara M, Jakubczyk A, et al. Characterization of Active Compounds of Different Garlic (Allium sativum L.) Cultivars. Polish J Food Nutr Sci. 2018; 68(1):7381.

7. Shang A, Cao SY, Xu XY, Gan RY, Tang GY, Corke H, et al. Bioactive compounds and biological functions of garlic (Allium sativum L.). Foods. 2019;8:1-31.

8. Hosseini $\mathrm{A}$, Hosseinzadeh $\mathrm{H}$. A review on the effects of Allium sativum (Garlic) in metabolic syndrome. J Endocrinol Invest. 2015; 38(11):1147-57.

9. Asdaq SMB. Antioxidant and hypolipidemic potential of aged garlic extract and its constituent, s-allyl cysteine, in rats. Evidence-Based Complement Alternat Med. 2015; 2015:328545.

10. Huang Y Te, Yao CH, Way CL, Lee KW, Tsai CY, Ou HC, et al. Diallyl trisulfide and diallyl disulfide ameliorate cardiac dysfunction by suppressing apoptotic and enhancing survival pathways in experimental diabetic rats. J Appl Physiol. 2013; 114(3):402-10.

11. Jang HJ, Lee HJ, Yoon DK, Ji DS, Kim JH, Lee CH. Antioxidant and antimicrobial activities of fresh garlic and aged garlic by-products extracted with different solvents. Food Sci Biotechnol. 2018; 27(1):219-225.

12. Zhai B, Zhang C, Sheng Y, Zhao C, He X, Xu W, et al. Hypoglycemic and hypolipidemic effect of S-allyl-cysteine sulfoxide (alliin) in DIO mice. Sci Rep. 2018;8:1-7.

13. Kim MJ, Kim HK. Effect of garlic on high fat induced obesity. Acta Biol Hung. 2011; 62(3):244-54.

14. Yang C, Li L, Yang L, Lu H, Wang S, Sun G. Anti-obesity and Hypolipidemic effects of garlic oil and onion oil in rats fed a high-fat diet. Nutr Metab. 2018;15:43:1-8.

15. Zhang $Y, X u$ L, Ding M, Su G, Zhao Y. Anti-obesity effect of garlic oil on obese rats via Shenque point administration. J Ethnopharmacol. 2019;231:486-493.
16. Chen YC, Kao TH, Tseng CY, Chang WT, Hsu CL. Methanolic extract of black garlic ameliorates diet-induced obesity via regulating adipogenesis, adipokine biosynthesis, and lipolysis. J Funct Foods. 2014;9(1):98-108.

17. Kagawa Y, Ozaki-Masuzawa Y, Hosono T, Seki T. Garlic oil suppresses high-fat diet induced obesity in rats through the upregulation of UCP-1 and the enhancement of energy expenditure. Exp Ther Med. 2019;19(2):1536-1540.

18. Shi X, Zhou X, Chu X, Wang J, Xie B, Ge J, et al. Allicin improves metabolism in high-fat diet-induced obese mice by modulating the gut microbiota. Nutrients. 2019;11(12):2909.

19. Zhang C, He X, Sheng Y, Xu J, Yang C, Zheng S, et al. Allicin Regulates Energy Homeostasis through Brown Adipose Tissue. iScience. 2020;23(5):101113.

20. Borlinghaus J, Albrecht F, Gruhlke MCH, Nwachukwu ID, Slusarenko AJ. Allicin: Chemistry and biological properties. Molecules. 2014; 19(8):12591-618.

21. Prati $P$, Henrique $C M$, Souza AS de, Silva VSN da, Pacheco MTB. Evaluation of allicin stability in processed garlic of different cultivars. Food Sci Technol. 2014;34:623-8.

22. Fujisawa H, Suma K, Origuchi K, Seki T, Ariga T. Thermostability of allicin determined by chemical and biological assays. Biosci Biotechnol Biochem. 2008;72(11):287783.

23. Gao W, Wang W, Zhang J, Deng P, Hu J, Yang J, et al. Allicin ameliorates obesity comorbid depressive-like behaviors: involvement of the oxidative stress, mitochondrial function, autophagy, insulin resistance and NOX/Nrf2 imbalance in mice. Metab Brain Dis. 2019;34(5):1267-80.

24. Zhou HR, Pestka JJ. Deoxynivalenol (vomitoxin)-induced cholecystokinin and glucagon-like peptide-1 release in the STC-1 enteroendocrine cell model is mediated by calcium- sensing receptor and transient receptor potential ankyrin-1 channel. Toxicol Sci. 2015;145(2):407-17.

25. Camacho S, Michlig S, De Senarclens-Bezençon C, Meylan J, Meystre J, Pezzoli M, et al. Anti-obesity and antihyperglycemic effects of cinnamaldehyde via altered ghrelin secretion and functional impact on food intake and gastric emptying. Sci Rep. 2015;5:7919.

26. Cao DS, Zhong L, Hsieh T han, Abooj M, Bishnoi $M$, Hughes $L$, et al. Expression of transient receptor potential ankyrin 1 (TRPA1) and its role in insulin release from rat pancreatic beta cells. PLoS One. 2012;7(5):e38005.

27. Macpherson LJ, Geierstanger BH, Viswanath V, Bandell M, Eid SR, Hwang SW, et al. The pungency of garlic: Activation of TRPA 1 and TRPV 1 in response to allicin. Curr Biol. 2005; 15(10):929-34.

28. Bautista DM, Movahed P, Hinman A, Axelsson HE, Sterner $\mathrm{O}$, Högestätt $E D$, et al. Pungent products from garlic activate the sensory ion channel TRPA1. Proc Natl Acad Sci U S A. 2005;102(34):12248-52.

29. Nikolic V, Stankovic M, Nikolic LJ, Cvetkovic D. Mechanism and kinetics of synthesis of allicin. Pharmazie. 2004;59(1):10-4.

30. Hatami T, Emami SA, Miraghaee SS, Mojarrab M. Total phenolic contents and antioxidant activities of different extracts and fractions from the aerial parts of artemisia biennis willd. Iran J Pharm Res. 2014;13(2):551-9.

31. Livak KJ, Schmittge $n$ TD. Analysis of relative gene expression data using real-time quantitative PCR and the $2^{-\Delta \Delta C T}$ method. Methods. 2001; 25(4):402-8. 
32. Uranga RM, Keller JN. The complex interactions between obesity, metabolism and the brain. Front Neurosci. 2019;13:513.

33. Bautista DM, Movahed P, Hinman A, Axelsson HE, Sterner $\mathrm{O}$, Högestätt ED, et al. Pungent products from garlic activate the sensory ion channel TRPA1. Proc Natl Acad Sci U S A. 2005;102(34):12248-52.

34. El-Sheakh AR, Ghoneim HA, Suddek GM, Ammar ESM. Attenuation of oxidative stress, inflammation, and endothelial dysfunction in hypercholesterolemic rabbits by allicin. Can J Physiol Pharmacol. 2016;94(2):216-224.

35. Lee CG, Rhee DK, Kim BO, Um SH, Pyo S. Allicin induces beige-like adipocytes via KLF15 signal cascade. J Nutr Biochem. 2019;64:13-24.

36. Suciu A, Tamaș V, Alexandru G, Bordei N. Evaluation of allicin stability in lyophilized aqueous garlic extract for new pharmaceutical solid formulations with bioavailable allicin. Journal of EcoAgriTourism. 2016;12(2):47-52.

37. Kuang J, Zhang Y, Liu Q, Shen J, Pu S, Cheng S, et al. Fatspecific Sirt6 ablation sensitizes mice to high-fat dietinduced obesity and insulin resistance by inhibiting lipolysis. Diabetes. 2017;66(5):1159-1171.

38. Cui XB, Chen SY. White adipose tissue browning and obesity. J Biomed Res. 2017;31(1):1-2.

39. Lee MS, Kim IH, Kim CT, Kim Y. Reduction of body weight by dietary garlic is associated with an increase in uncoupling protein mRNA expression and activation of AMP-activated protein kinase in diet-induced obese mice. J Nutr. 2011;141(11):1947-53.

40. Wei Q, Lee JH, Wang $\mathrm{H}$, Bongmba OYN, Wu CS, Pradhan $\mathrm{G}$, et al. Adiponectin is required for maintaining normal body temperature in a cold environment. BMC Physiol. 2017;17(1):8.

41. Cannon B, Nedergaard J. Brown Adipose Tissue: Function and Physiological Significance. Physiol Rev. 2004;84(1):277-359.

42. Fromme T, Klingenspor M. Uncoupling protein 1 expression and high-fat diets. Am J Physiol Regul Integr Comp Physiol. 2011;300(1):R1-8.
43. Baboota RK, Murtaza N, Jagtap S, Singh DP, Karmase A, Kaur J, et al. Capsaicin-induced transcriptional changes in hypothalamus and alterations in gut microbial count in high fat diet fed mice. J Nutr Biochem. 2014;25(9):893902.

44. Liu Z, Patil IY, Jiang T, Sancheti H, Walsh JP, Stiles BL, et al. High-fat diet induces hepatic insulin resistance and impairment of synaptic plasticity. PLoS One. 2015;10(5):e0128274.

45. Padiya R, Khatua TN, Bagul PK, Kuncha M, Banerjee SK. Garlic improves insulin sensitivity and associated metabolic syndromes in fructose fed rats. Nutr Metab (Lond). 2011;8:53.

46. Gribble FM, Reimann F. Function and mechanisms of enteroendocrine cells and gut hormones in metabolism. Nat Rev Endocrinol. 2019;15(4):226-237.

47. Levin F, Edholm T, Schmidt PT, Grybäck P, Jacobsson $H_{\text {, }}$ Degerblad $M$, et al. Ghrelin stimulates gastric emptying and hunger in normal-weight humans. J Clin Endocrinol Metab. 2006;91(9):3296-302.

48. Schmid DA, Held K, Ising M, Uhr M, Weikel JC, Steiger A. Ghrelin stimulates appetite, imagination of food, $G H$, ACTH, and cortisol, but does not affect leptin in normal controls. Neuropsychopharmacology. 2005;30(6):118792.

49. Timper K, Brüning JC. Hypothalamic circuits regulating appetite and energy homeostasis: Pathways to obesity. Dis Model Mech. 2017;10(6):679-689.

50. Sandrini L, Di Minno A, Amadio P, leraci A, Tremoli E, Barbieri SS. Association between obesity and circulating brain-derived neurotrophic factor (BDNF) levels: Systematic review of literature and meta-analysis. Int J Mol Sci. 2018;19(8):2281.

51. Babes A, Fischer MJM, Filipovic M, Engel MA, Flonta $\mathrm{ML}$, Reeh PW. The anti-diabetic drug glibenclamide is an agonist of the transient receptor potential Ankyrin 1 (TRPA1) ion channel. Eur J Pharmacol. 2013;704(1-3):1522. 


\section{Ekstrakt crnog luka bogat alicinom ublažava komplikacije izazvane visokomasnom ishranom kod pacova: Nutrigenomska studija}

1,2Neha Mahajan, 1,3Vijay Kumar, 1,2Ruchika Maurya, ${ }^{4}$ Pragyanshu Khare, ${ }^{6}$ Priyanka Mangal, ${ }^{7}$ Rohini Verma, ${ }^{1,5}$ Vibhu Kumar, ${ }^{1,5}$ Jasleen Kaur, ${ }^{7}$ Sanjay Madhukar Jachak, ${ }^{1}$ Kanthi Kiran Kondepudi, ${ }^{1 *}$ Mahendra Bishnoi

${ }^{1} T R(i) P$ for Health Laboratory, Centre of Excellence in Functional Foods, Department of Food and Nutritional Biotechnology, National Agri-food Biotechnology Institute (NABI),

Knowledge City-Sector-81, SAS Nagar, Punjab 140306, India;

${ }^{2}$ Regional Centre for Biotechnology, Faridabad-Gurgaon expressway, Faridabad, Haryana 121001, India;

${ }^{3}$ Department of Biotechnology, Panjab University, Sector-25, Chandigarh 160014, India;

${ }^{4}$ Department of Anesthesiology, UniClinic, Erlangen, Friedrich-Alexander-Universität, Erlangen-Nürnberg, Germany;

${ }^{5}$ Pharmacology Division, University Institute of Pharmaceutical Sciences (UIPS), Panjab University, Chandigarh 160014, India;

${ }^{6}$ Department of Pharmacology and Toxicology, National Institute of Pharmaceutical Education and Research (NIPER), SAS Nagar 160062, Punjab, India;

${ }^{7}$ Department of Natural Products, National Institute of Pharmaceutical Education and Research (NIPER), SAS Nagar 160062, Punjab, India.

\begin{abstract}
Kratak sadržaj
Lekovito dejstvo crnog luka pri različitim metaboličkim komplikacijama pripisuje se raznovrsnim organskim sumpornim jedinjenjima, kao što su alicin, dialil sulfidi, aliin i alil trisulfidi. U ovoj studiji izolovani su vodeni ekstrakti crnog luka sa stabilnim alicinom $i$ ispitivani njihovi biološki tkivno specifični nutrigenomski efekti u sprečavanju gojaznosti $i$ povezanih komplikacija izazvanih visokomasnom ishranom (HFD) u Sprague-Dawley (SD) pacovima. Pripremljen je rastvor ekstrakta crnog luka bogat alicinom (ARGE), a stabilnost alicina okarakterisana je HPLC metodom. Za biološku evaluaciju životinje su hranjene 16 nedelja normalnom hranom, visokomasnom hranom, visokomasnom hranom zajedno sa ARGE (1 $\mathrm{ml} / \mathrm{kg}$ p.o.) ili samim ARGE $(1 \mathrm{ml} / \mathrm{kg}$ p.o.). Hronična administracija ARGE sprečila je gojenje izazvano visokomasnom ishranom, hipertrofiju masnog tkiva, insulinsku rezistenciju i generalno je dovela do poboljšanja glukozne homeostaze. Transkripciona analiza različitih tkiva pre svega je pokazala da ARGE promoviše browning, pospešuje glukozni metabolizam i regulaciju apetita. Ova studija pokazuje da ARGE ima nutraceutski potencijal u prevenciji gojaznosti i povezanih komorbiditeta.
\end{abstract}

Ključne reči: $A R G E$, ekstrakt crnog luka bogat alicinom; TRPA1; gojaznost; mrko masno tkivo; belo masno tkivo; dialil disulfidi; dialil trisulfidi; insulinska rezistencija; WAT browning; hormoni creva. 